\title{
脳における情報処理と可塑性の 神経生理学的背景について
}

\author{
川平和美* 田中 信行
}

\section{はじめに}

近年のブレインサイエンスの発展は中枢神経系 における情報処理過程を細胞レベルで急速に解明 しつつあり，同時に FMRI (functional magnetic resonance imaging) や脳磁図, PET (positron emission computed tomography) などの発展は ヒトの脳における機能の局在や損傷後の機能回復 についての検討を可能にして，この領域の知識を 飛躍的に増やしている。これらの情報は実際の脳 損傷例のリハビリテーションにおいても新しい視 点と理論の発展をもたらすものである．脳の情報 処理の特徵と随意運動のメカニズムに触れながら 脳損傷後の機能回復の背景にある可塑性について も述べる.

\section{脸は階層処理か並列処理}

近年，脳の情報処理は，従来考えられていた階 層処理ではなく並列処理であることが明らかに なった ${ }^{1)}$. 視覚情報処理を例に挙げて説明すると， 階層処理では対象の形や色，動き等の属性は一緒 に処理され，次々により複雑な処理を行う高位の 処理段階を経て最終的に認識に至る。これに対し て並列処理では，図 1 に示すように，視覚情報は その第一歩である網膜からすでに形態視系（色彩
視や形態視の情報）と運動視系（対象の運動や空 間的位置の情報）に分かれてそれぞれの系の中で の階層的な処理を経て認知に至る。右の視野にあ る対象の色彩や形態の情報は左半球の一次視覚野 （V1）から V2，V3 を経て色彩視の中枢（紡鍾状 回：V4), 側頭連合野への系で処理され, 対象の運 動や位置に関する空間視の情報は一次視覚野 (V1) から V2，V3 を経て頭頂連合野への系で処 理され，対象の運動方向（V5）や空間的な位置 (V6) が認識される ${ }^{2,3)}$.

サルの実験で得られた関連深い事実を挙げる と, 側頭葉には手など特定の物体に反応する細胞, 特定の個人の顔に反応する細胞（おばあちゃん細 胞 $)^{4)}$ 等が，頭頂葉には奥行き運動に反応する細 胞，物体の三次元的傾きを識別する細胞，網膜の 特定の位置に対象があるときに反応する細胞，自 己の身体から特定の位置に対象があるときに反応 する細胞绵などが知られている.

もちろん，並列処理の途中でも他の処理系との 情報交換がなされるので，1つの対象が色や形， 運動方向等がばらばらに認知されることはない. 臨床例でも形態視系のみの損傷 (大脳性色覚異常, 物体失認, 相貌失認) あるいは運動視系のみの障 害（視覚失調，大脳性運動盲）など，2つの両視 覚処理系の乘離した障害がみられ，並列処理を裏 づけている6,7). 


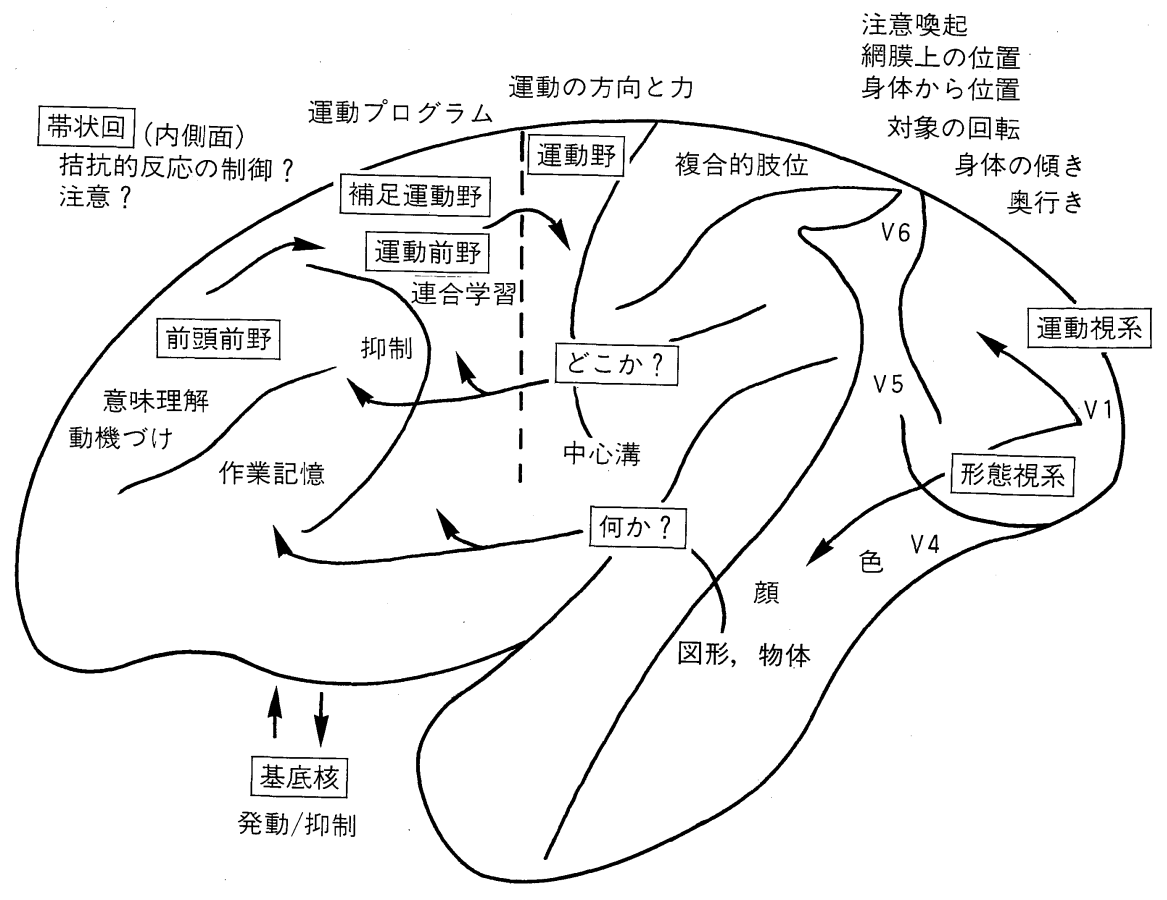

図 1 視覚情報処理と随意運動

神経細胞の活動記録で認められた機能を中心に，視覚処理と随意運動に関連する機能局在を示す．

これらの視覚情報を受ける他の領域には，視覚 情報と他の知覚情報にも反応する細胞が存在す る. 頭頂葉には他人の手が近づいても自分の手を 近づけても反応する細胞帛が，運動前野には手の 位置 (固有知覚) を変えると視覚刺激の受容野が 変化する細胞 ${ }^{9}$ がある.

\section{随意運動のメカニズム}

随意運動は，まず外部からの刺激の認知（側頭 葉や頭頂葉の連合野), 刺激の意味や洞察などの総 合的判断とそれに対する行動の選択つまり意思決 定 (前頭連合野)，外部刺激に対応して自動的に セットされた複数の運動プログラム（運動前野や 補足運動野，基底核，小脳）のなかから最も目的 にかなったものの選択，遂行（一次運動野）とい う段階を踏んで行われる。

「台の上のリンゴに手を伸ばす」場合を運動の 神経機構モデル ${ }^{10)} に$ 従って説明すると，頭頂葉連 合野で空間軸でのリンゴの位置情報（どこに：距
離 $50 \mathrm{~cm}$, 縦に, 静止), 次にそれを体軸での位置 情報（どのような肢位にあたるか：肩屈曲 30 度, 肘屈曲 45 度…) に変換し, 現在の手の位置から到 達目標までの実現すべき運動が運動前野や補足運 動野でプログラムされ，一次運動野でその運動方 向と力が筋活動の情報に変換される ${ }^{11)}$.しかし, 現 実の運動プログラムと神経活動の関連について は，やっと眼球運動をプルキンジェ細胞の細胞活 動を用いた計算モデルで表すことができた段階で ある ${ }^{12)}$.

\section{1 前頭葉の機能分担}

簡単に前頭葉の機能分担に触れるが，サルでは 9 つの皮質運動領野が知られており，七トでは もっと複雑なものが予想される。

\section{1) 前頭前野}

前頭前野は刺激の意味理解 ${ }^{13)}$ と辺縁系からの情 動的な情報を背景にしながら動機づけ（報酬に関 連した細胞 $)^{14)}$, 意思決定を行うほか, 遅延反応で 誘導刺激から反応刺激の間だけ次に何をするか記 
補足運動野
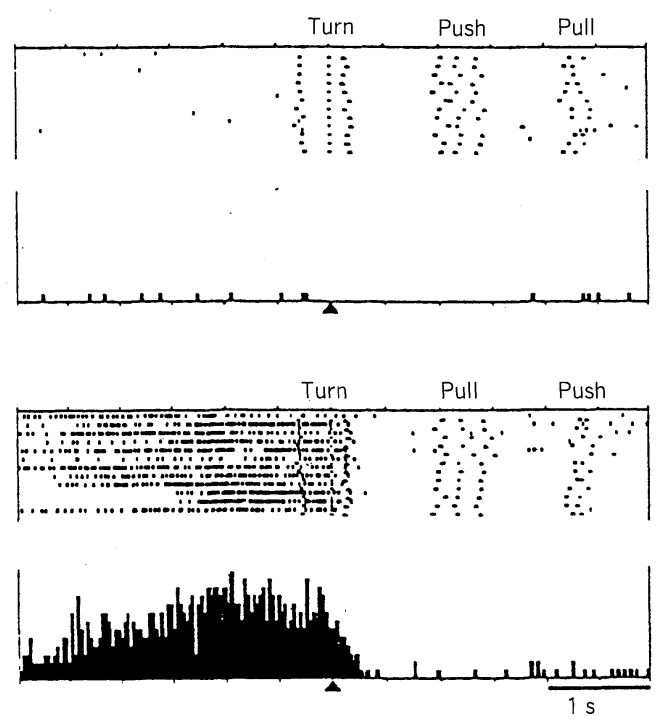
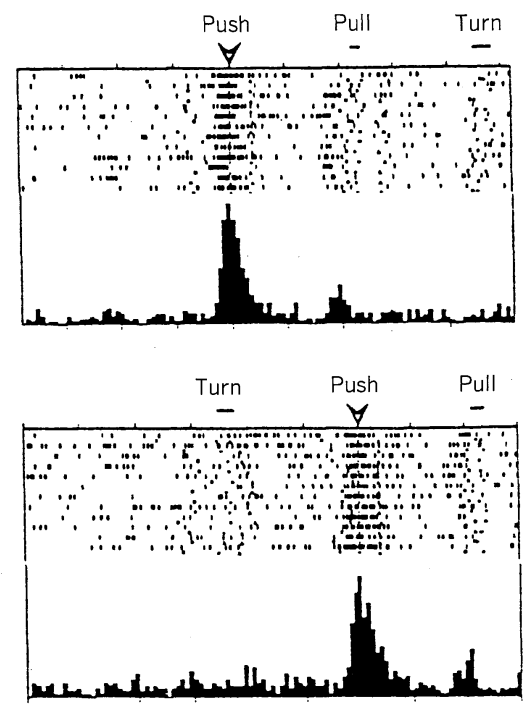

図 2 補足運動野の特定の連続動作に関連する神経細胞活動 ${ }^{24)}$

サルが習熟したレバー操作を記憶に基づいて行っているときの補足運動野と一次運動野の細胞活動の記 録を示す．左側に示す補足運動野のこの細胞は, レバーを「回す・押す・引く」の順に操作するとき（左 上段）は活動しないが, 「回す・引く・押す」の順に操作するとき（左下段）に操作開始前に活動し, 操 作を始めると活動は止む。つまり，この補足運動野の神経細胞は「回す・引く・押す」の一連の操作を コードしている。 これに対して，右側に示す一次運動野のこの細胞は操作の順番に関係なく「押す」動 作の間に活動する。(Tanji の成績を改変)

憶 $(\text { 作業記憶 })^{15,16)}$, 反応の選択と抑制を行ってい る.とくに反応の抑制は運動前野に近い領域が重 要で, ヒトでも動物でも行為を抑制する際に抑制 電位 (NO-Go 電位) が出現し ${ }^{17,18)}$, 活動を阻害す ると行動の抑制が困難になる ${ }^{19)}$.

前頭前野の損傷が知的レベルに与える影響は, 思考の柔軟性低下 (ステレオタイプな思考と行動) や新しい環境での適応困難 ${ }^{20)}$, 短期記憶の障害 ${ }^{21)}$ がある。

\section{2 ）運動前野と補足運動野}

運動前野は刺激と反応（行動）を結びつける条 件連合学習の中心で ${ }^{22)}$, 日頃の生活のなかで繰り 返される刺激 - 反応の結果, 種子を摘むときだけ, あるいは丸い棒を握るときだけ ${ }^{23)}$, レバーを右に 動かすときだけ（右手で行っても, 左手で行って も活動する）のように特定の運動で活動する細胞 が形成される. 運動前野の細胞は, 一次運動野の 細胞と異なり運動開始に先だって活動し, 運動開
始後は活動しないので，プログラムのセットを 行っていると考えられている。

補足運動野は習熟した連続動作のプログラムを セットする役割をもち, 図 2 に示すように, 特定 の連続動作の開始前にのみ活動が高まる細胞が見 つかる ${ }^{24)}$.

ヒトでも運動前野が刺激に対応したプログラム のセット，補足運動野が外的な手がかりによらな い習熟した連続動作のプログラムのセットとの機 能分担が認められる. 運動前野の障害は刺激と特 定の上肢の肢位とを対応づけて覚えることを困難 にし ${ }^{25)}$, 補足運動野の血流増加は外的信号でレ バーを動かすときより自分で方向を選んで動かす ときに著しい ${ }^{26)}$.

基底核は前頭前野や運動前野, 補足運動野と密 接に関連しながら，随意運動の発現を制御してい る.サルでは補足運動野の損傷による自発的な行 為の開始困難は; 外的な誘導刺激で運動前野から 
の運動誘発を重ねると軽減される ${ }^{27)}$. パーキンソ ン病の initial hesitation や歩行失行が階段や床 の目印で軽減する現象は, 補足運動野あるいは基 底核の障害による運動開始困難を運動前野の働き で軽減しているとの解釈も可能である.

\section{3) 運動野}

運動野でもそそれ゙れの細胞は特定の方向 (preferred direction) に手を伸ばすときに活動が 高まり，その方向からはずれるにつれて活動は減 少する.手に外力を加えたりして条件を変えると, 活動の様式が変化するものもあることから, 特定 の運動方向（肩関節に扔ける角度）や筋出力の情 報に関係している ${ }^{11)}$ と考えられている.

\section{2 運動学習}

ヒトが新しい運動パターンを学習するとき，初 期は興奮性が高い領域 (磁気刺激への閾值の低下) が運動野に広がり, 習得後は急速に縮小するこ と ${ }^{28)}$, 複雑な指の連続運動を学習するときの脳血 流は運動学習中は補足運動野を中心に前頭葉の皮 質と小脳において増えるが, 習得後はそれらは減 少し, 代わって線状体の血流が増えること ${ }^{29)}$, 自分 の手で物をつかむことをイメージするだけでも前 頭葉の多くの領域と頭頂葉の血流が増えること ${ }^{30)}$ から，新しいプログラムを作るためには前頭葉の 多くの領域の関与が必要だが，それが出来上がる と特定の細胞群にコードされる. そして, 単にイ メージするときにもそれらのプログラムをシミュ レーションさせていると考えられる。

\section{行為の障害と兴のメカニズム}

行為を困難にしているメカニズムを考える際 に, 参考になるものを幾つか取り上げる ${ }^{311}$. 行為の 発現と抑制の障害として, 組織化された一見合目 的な行為が, 本人の意志によらず発現する道具の 強迫的使用と保続等を, 行為が意図どおりに遂行 されない障害として観念失行に触れる。

\section{1 ) 道具の強迫的使用}

道具の強迫的使用は「学習された行為レベルの 運動パターンが開放されたもの」 ${ }^{32)}$,つまり外的刺
激（道具）に対応して運動前野に自動的にセット される道具操作のプログラムへの前頭前野の抑制 が不十分で暴走を始めたものと考えられる。確認 された病巣は左前頭葉内側面（前部帯状回, 補足 運動野) と脳粱を含み ${ }^{32)}$, 必ずしも前頭前野にある 行動抑制の領域を直接損傷するものでなくとも帯 状回, 補足運動野, 脳粱の障害が抑制力を低下さ せると考えられる. 補足運動野の損傷による強制 把握はまさに触覚刺激に反応せずにはいられない 状態であることを考えれば納得できる.

\section{2 ) 保 続}

保続は「一度始めた行為の不適切な繰り返し」 で，前頭前野の反応の選択と抑制の機能が低下し た状態と考えられるが，前頭前野自体，ことに反 応抑制の領域だけでなく，後述するプログラムを セットする運動前野や補足運動野の機能低下も関 連している。これを裏づけるように臨床例でも, 前頭葉損傷では運動性保続（例：机を 2 回吒くべ きところを 3 回吒いてしまう）は多いが書字や図 形模写での保続は少なく, 内容的には要素動作の 保続, 企図保続（例：机を右手で吒いて，次に左 手で吒くべきところを, 最初から左手で吒いてし まう）が多く, 病巣の大きさと相関するのは企図 保続だけである。その他の領域の損傷例では要素 動作の繰り返しゃ反応の終了困難は少なく, 書字 や図形模写での保続と反応の選択の障害「取り違 え(錯行為)」が増える ${ }^{33}$.

\section{3 ) 観念失行}

観念失行（道具使用の障害）は検査場面（机に 置かれた箸を使う)では顕著でも日常生活場面(実 際の食事)では認められないことが多い.つまり, 日頃箸とともに存在する食器や食べ物など多くの 刺激がある生活場面では, 多重的な刺激が運動前 野や補足運動野に適切なプログラムのセットを可 能にし, 失行が軽減することを意味しているが, このことは道具操作のプログラム自体はよく保持 されているにもかかわらずそのセットならびに連 続的なプログラムの切り替えに問題があることを 示す．原因は，それに必要な情報が側頭連合野(何 か）や頭頂連合野（どこか，どの肢位か）から十 分届かないことで, 一種の離断症状としての理解 
が適切と思われるが31)，責任病巣が多い頭頂葉に 行為のプログラム (エングラム)があるとの考方 ${ }^{34)}$ も根強い．頭頂葉連合野自体の損傷あるいは運動 前野や補足運動野との連合線維の損傷では歯ブラ シを持っての歯磨き動作を耳元で行うような行為 の空間的な誤りや，他人の身ぶりを模倣できない 状態，つまり視覚情報（相手の肢位）と身体固有 知覚（対応する自分の肢位）の連合障害も起こっ て不思議はない.

\section{記憶のメカニズム}

記憶を保持時間で分けると，瞬時，近時，遠隔 記憶に分けられるが，どのような神経機構の変化 と対応しているのであろうか.

瞬時記憶に相当する遅延反応（手がかり刺激が 消えてから反応刺激の間：次に何をするかを記 憶）では前頭前野にこの間だけ活動を続ける細胞 があり, 見本合わせ課題（見本提示から次の試料 が示されるまでの間：見本を記憶）では刺激の受 容野かその連合野にこの間だけ活動を続ける細胞 がある ${ }^{35)}$. 海馬にある近時記憶を連合野に遠隔記 憶として残す際の海馬の重要な役割は，連合的な 機能つまり大脳皮質の各領域を結びつける配線板 の役割である ${ }^{36)}$. バラの花を手に取ると, 花の色, 形, 香り, 棘の痛みを感じるが, 色, 形, 香り, 痛みの知覚野の皮質を海馬は同時的に興奮させ, それぞれの皮質間の相互的な連合的結合を形成さ せる，そのため，長期記憶が形成された後はバラ の写真を見ても花の香りや棘の痛みを思い出し, 意識はされないが棘に刺されない持ち方の運動プ ログラムが準備される。

\section{可塑性}

可塑性とは一度ある機能を獲得した神経細胞が 他の機能を獲得する能力を意味する．可塑性が高 いことは, 細胞が機能的に柔軟で，損傷後の機能 回復もよいことを意味する。まず，実際に可塑性 がどれくらい認められるか, 次にその発現メカニ ズムと影響する要因について触れる。

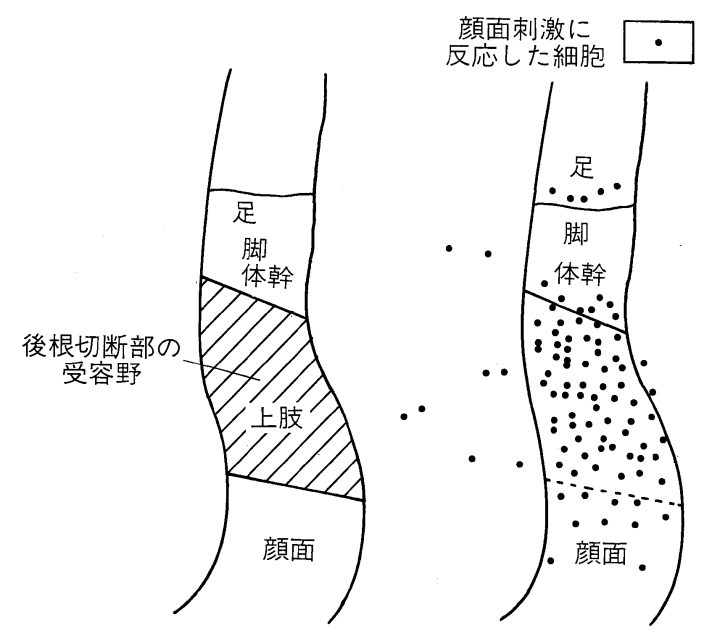

図 3 頸部後根切断による知覚受容野の変化 ${ }^{37)}$ サルの頸部後根切断により上肢からの感覚入力がなくなっ た上肢の知覚受容野は顔の受容野となり，この顔と上肢の 境界の移動は十数 $\mathrm{mm}$ もあった。

\section{1 可塑性の証明}

脳は情報処理量に応じてダイナミックに役割の 変更を行っている。体性知覚野については, 図 3 に示すように, サルの前肢の知覚入力を断つと前 肢の受容野は顔の受容野になり ${ }^{37)}$, ヒトでも上肢 切断例の切断肢の受容野は顔の受容野になる ${ }^{38)}$. ある指の受容野を切除すると隣接した皮質がその 指の受容野に変わるし ${ }^{39)}$, 特定の指先に多くの刺 激を与えるとその受容野は著しく拡大する ${ }^{40)}$.

ヒトにおける上肢切断例の幻肢痛は切断肢の受 容野が顔の受容野に大きく置き換えられた例ほど 強いことから ${ }^{41)}$, 幻肢痛発生にも脳における可塑 性の発現が関与し，大きな受容野の変更につなが る切断肢断端からの知覚入力減少が幻肢痛の一因 となることを示唆している.

運動野について, ラットでは一側の運動野切除 後, 健側半球が同側肢への支配を強めており ${ }^{42)}$, 顔 面神経を切断すると数時間で顔面筋の支配野の一 部は前肢の支配野に変わった ${ }^{43)}$. ヒトでも経皮的 磁気刺激を用いた検討で, 大脳半球切除後は健側 半球の同側肢 (麻痺肢) への支配が強まり, 看䯣 損傷や下肢切断では支配する肢体を失った運動野 は隣接する健常部を支配するようになる ${ }^{44)}$. 
視覚野皮質

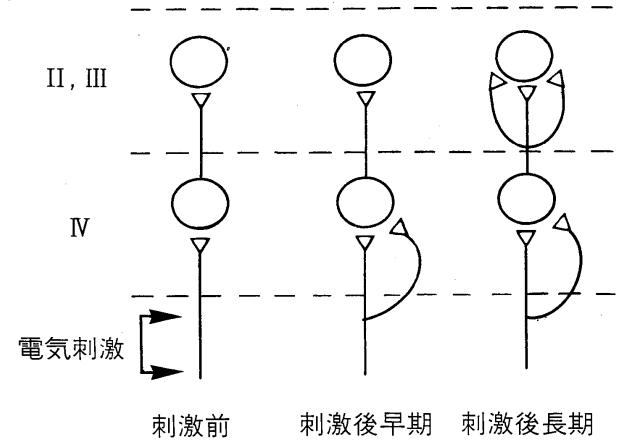

図 4 電気刺激による長期増強に伴うシ ナプス变化のシェーマ47)

\section{2 可塑性のメカニズム}

機能局在の背景となっている機能別の組織化 は，先天的にプログラムされた大脳皮質の 6 層間 の連絡と情報処理量など後天的要素によって決ま るコラム(約 $0.5 \mathrm{~mm}$ 径の円柱状に類似の機能を もった細胞が集合）の形成により行われている.

近年，成熟後の脳も大きな可塑性をもつことが 明らかにされ，その背景にはアンマスキングや神 経側芽, NMDA (N-metyl-D-aspartate) 型シナ プスの関与した長期増強 (LTP : long-term potentiation) や長期抑制 (LTD : long-term depression) 等のシナプスの伝達効率の変化も関 与している ${ }^{45)}$.

可塑性発現に最も関連するシナプスの伝達効率 は Hebb の概念やコバリアント理論に従ってお り, シナプス前線維の興奮がシナプス後神経細胞 を興奮させればそのシナプス伝達効率は強まり， 逆の場合は弱まる ${ }^{46)}$. したがって, 外的な操作でシ ナプス後細胞を閾値近くまで興奮水準を上げてシ ナプス前線維の不十分な興奮でもシナプス後細胞 の興奮につながるようにするか，図４に示すよう に単純にシナプス前線維の電気刺激を行うこと で ${ }^{47)}$, 繰り返しシナプス後細胞を興奮させれば伝 達効率が高くなり新たな神経回路の形成につなが る.

ここでは図 5 に示すアンマスキングと神経側 芽の 2 つを取り上げる.

\section{1) 神経側芽}

神経側芽の発生は損傷後 1 力月前後が最も多 sprouting
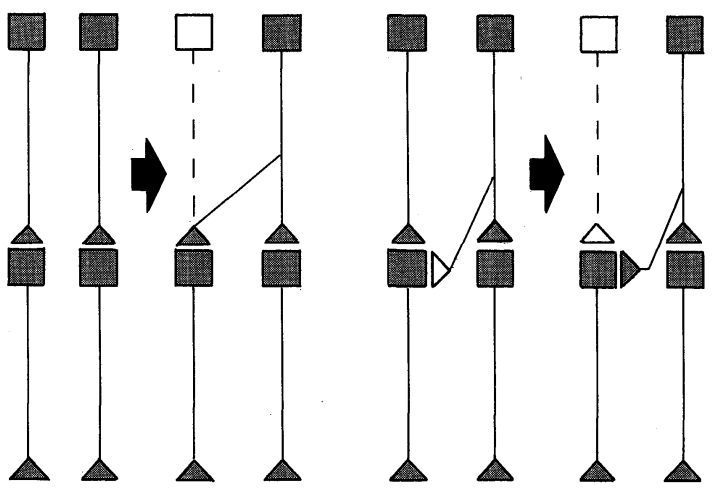

図 5 神経側芽とアンマスキング

く，その後は減少する。つまり，一度は多数の神 経側芽が生ずるが, 無用のものは消滅してしまう. 可塑性の機能面への関与は明らかでない部分も多 (2.

\section{2 ) アンマスキング (unmasking)}

神経細胞は他の多くの神経細胞とシナプスで結 合しているが，日頃は抑制されてその存在は気づ かれない.しかし，神経損傷が起こると抑制がと れて伝達路としての働きが数時間で表面化する。 知覚入力を断たれると，その受容野の GABA（抑 制系神経細胞の伝達物質）が一時的に減少する が48)，この時期は可塑性が高まっていると考えら れる。

\section{3 可塑性発現に影響する要因}

脳損傷後の可塑性発現は, 若いほどよく, 切除 量は同じでも 1 回切除より数回に分けての切除が よく，追加切除までの期間が長いほどよい．同一 半球内で運動野と他の皮質を併せて切除をした場 合, 運動野と体性知覚野の切除では機能回復の悪 化はないが，運動野と運動前野の切除は機能回復 が悪くなる. 運動野切除と脳粱切断を行っても機 能回復は影響されない49).

多くの破壊実験の成績を比較すると，単純に脳 損傷が大きいほど重度の機能障害を招くとは限ら ず50), 表 1 に示すように, 脳損傷によるてんかん例 への半球切除術は障害半球の健常な脳まで切除す るため脳の損傷を拡大させるにもかかわらず麻痺 
表 1 大脳半球切除を受けた 150 例の調査 ${ }^{51)}$

\begin{tabular}{|c|c|c|c|c|c|}
\hline 手術成績 & 片麻摩 & 人格障害 & 知能障害 & \multicolumn{2}{|c|}{ 㽷攀 } \\
\hline 改善 & $32.7(\%)$ & 80.5 & 69.7 & 消失 & 67.4 \\
\hline \multicolumn{2}{|c|}{ 瘥性減少|3.3 } & & & 減少 & 13.2 \\
\hline 不変 & 30.7 & 2.1 & 7.6 & & 2.8 \\
\hline 悪化 & 6.0 & 0 & 2.3 & & 0 \\
\hline 不詳 & 10.7 & 9.9 & 15.1 & & 9.7 \\
\hline 死亡 & 6.6 & 7.5 & 5.3 & & 6.9 \\
\hline
\end{tabular}

対象は脳損傷後のてんかんに苦しむ患者 150 名.

や知能障害などの障害を軽減する ${ }^{51)}$ ，これらの事 実は傷害された脳が健常な脳における可塑性発現 を阻害している可能性を示している.

運動療法の大切さを示すものでは，サルの両側 大脳のすべての皮質を約 2 年かけて段階的に切除 したにもかかわらず，手術の次の日から関節可動 域訓練と歩行訓練を積極的に行った研究施設では 歩行可能になったが52)，放置した研究施設では もっと狭い皮質切除でサルは拘縮や裖瘡が原因で 死んでいる.

機能回復を促進するには，神経側芽やアンマス キングによるダイナミックな神経路の組み替えが 行われている時期に，位置覚や運動覚など多くの 知覚入力を与え，同時に必要な運動パターンの獲 得を図るために自他動運動を多く繰り返すことが 必要である。より効果的な訓練とするためには, 患側肢を注視させて意図した運動と現実に生じた 運動の差を常に意識させることで，視空間軸での 位置情報や肢位の情報を自己の身体軸での肢位の 情報に変換し，さらにそれに従って患側肢を動か すに必要な神経回路の形成を促すこと, 訓練課題 に関連する領域の神経細胞の反応性を高めるた め，操作あるいは注意を高めたい空間に患側肢を 置いたり ${ }^{9)}$ 「今から……ますよ」等の予告や注 意の喚起を繰り返すこと ${ }^{53,54)}$ が必要である．新し い神経回路を作りたければ，その回路を構成する シナプス前線維の興奮がシナプス後神経細胞を興 奮させることを繰り返す以外にない ${ }^{45,46)}$.

\section{おわりに}

最近の神経生理学的事実は，脳は情報処理を並
列処理で行い，かつて概念的な理解にとどまって いた認知や随意運動のメカニズムを細胞レベルの 情報処理過程として明らかにしている，脳の可塑 性についても同様に細胞レベルあるいはシナプス レベルでの理解を可能にしつつある．動物が示す 脳損傷後の機能回復のよさに比べて，脳卒中患者 の機能回復はあまりに悪い。ヒトは動物より大き く複雑な中枢神経をもち，歩行や道具使用など複 雑な運動を行い，内包や基底核，視床など深部病 変が多いなど,その回復の差を生む要因は多いが, その一部に脳の可塑性の高まっている時期のリハ ビリテーション的な対応に問題があるのではない かとの危惧を感ずる，近年のブレインサイエンス が明らかにした基礎的な事実をもっと実際の運動 療法や作業療法に取り込みながら，現在の促通手 技に多い非科学的ドグマを除いて，機能レベルで の障害軽減につながる真に有効な促通手技の確立 に努力する必要がある。

\section{文 献}

1）酒田英夫：空間認知と動作指向性知覚. 甘利俊一，酒 田英夫 (編) : ニューラルネット. 朝倉書店, 東京, 1994, pp. 93-116.

2）三上章允：サルの大脳皮質の視覚情報処理。三上章允 （編）：視覚の進化と脳. 朝倉書店, 東京, 1993, pp. 105 -130 .

3）Zeki S（河内十朗 訳）：脳のヴィジョン．医学書院， 東京, 1995, pp. 189-199.

4) 岩井栄一：側頭葉. 入来正躬, 外山敬介(編): 生理学. 文光堂, 東京, 1986, pp. 415-448.

5) Galletti C, Battaglini PP, Fattori P : Parietal neurons encoding spatial locations in claniotopic coordinates. Exp Brain Res $96: 221-229,1993$.

6) Zeki S (河内十朗 訳)：脳のヴィジョン. 医学書院, 東京, 1995, pp. 269-292.

7）緒方敦子，東郷伸一，川津 学，川平和美・他：紡鍾 状回梗塞により大脳性色覚異常と連合型視覚失認, 相 貌失認を呈した患者の症状と経過。神経心理学 11(3).

8）酒田英夫：頭頂葉. 入来正躬，外山敬介(編)：生理学. 文光堂, 東京, 1986, pp. 396-414.

9) Graziano MSA, Yap GS, Gross CG : Coding of visual space by premotor neurons. Science 266 : 1054-1057, 1994

10）川人光男：運動の神経機構モデル. Brain Medical 6 : 371-377, 1994.

11) Karaska JF, Crammond DJ : Cerebral cortical mechanisms of reaching movements. Science 20 : 1517-1523, 1992. 
12) Shinohara M, Kawano K, Gomi H, Kawato M : Inverse-dynamics model eye movement control by Purkinje cells in the cerebellum. Nature $365: 50$ $-52,1993$.

13) Watanabe $\mathrm{M}$ : Frontal units of the monkey coding the associative significance of visual and auditory stimuli. Exp Brain Res 89 : 233-247, 1992.

14) Watanabe $M$ : Prefrontal unit activity during associative learning in the monkey. Exp Brain Res $80: 296-309,1990$.

15) Niki H, Watanabe $M$ : Prefrontal unit activity and delayed response : relation to cue location versus direction of response. Brain Res 105:79-88, 1976.

16) Sawaguchi $T$, Matsumura M, Kubota $K$ : Delayed response deficits produced by local injection of bicuculline into the dorsolateral prefrontal cortex in Japanese macaque monkeys. Exp Brain Res 75 : 457-469, 1989.

17）内藤栄一, 松村道一, 田口貞善：異なるタイプのストッ プシグナル課題中のヒト運動抑制関連電位の解析. 日 本生理誌 $57: 59-68,1995$.

18）佐々木和夫：前頭葉の事象関連電位と脳磁図. 神経進 歩 $37: 72-81,1993$.

19) Oishi $T$, Kubota $K$ : Disinhibition in the monkey prefrontal cortex, by injecting bicuculline, induces forelimb movements learned in a GO/NO-GO task. Neurosci Res 8:202-209, 1990.

20) Prigatano GP: The relationship of frontal lobe damage to diminished awareness: Studies in rehabilitation. In Levin HS, Eisenberg HM, Benton AL (eds) : Frontal Lobe Function and Dysfunction. Oxford University Press, New York, 1991, pp. 381 $-397$.

21) Shimamura AP, Janowsky JS, Squire LR : What is the role of frontal lobe damage in memory disorders. In Levin HS, Eisenberg HM, Benton AL (eds) : Frontal Lobe Function and Dysfunction. Oxford University Press, New York, 1991, pp. 173 -195 .

22）丹治 順：運動関連領野と運動プログラミング。甘利 俊一, 酒田英夫 (編) : 脳とニューラルネット。朝倉書 店, 東京, 1994, pp. 203-217.

23) Rizzolatti $G$ : Functional organization of inferior area 6. In: Motor areas of the cerebral cortex. John \& Wiley, Chichester, (Ciba Found Symp 132), 1987, pp. 187-200.

24) Tanji J, Shima K : Role for supplementary motor area cells in planning several movements ahead. Nature 371:413-416, 1994.

25) Halsband H, Freund $\mathrm{H}-\mathrm{J}$ : Premotor cortex and conditional motor learning in man. Brain 113 : 207-222, 1990.

26) Colebatch JG, Deiber M-P, Passingham RE, Friston $\mathrm{KJ}$, et al: Regional cerebral blood flow during voluntary arm and hand movements in human subjects. J Neurophysiol 65 : 1392-1401, 1990.

27) Passingham RE, Chen YG, Thaler D : Supplemen- tary motor cortex and self-initiated movement. In Ito M (ed) : Neural Programming. Karger, Tokyo, 1989, pp. 13-24.

28) Pascual-Leone A, Grafman J, Hallett M : Modulation of cortical motor output maps during development of implicit and explicit knowledge. Science 263 : 1287-1289, 1994.

29) Seitz RJ, Roland E, Bohm $\dot{C}$ : Motor learning in man ; a positron emission tomographic study. Neuroreport $1: 57-60,1990$.

30) Decety J, Parani D, Jeannerod M, et al : Mapping motor representations with positron emission tomography. Nature 371:600-602, 1994.

31）川平和美, 田中信行：随意運動のメカニズム，総合リ 八 22:491-496, 1994.

32) 森 悦朗, 山鳥 重：前頭葉と行為障害: 神経進歩 37:127-138, 1993.

33）鹿島晴雄, 佐久間啓 : 脳損傷と保続 ; Luria の理論と 運動性保続について。神経内科 36：332-341， 1992.

34）大東祥孝：失行の説明仮説と局在. 島薗安雄, 保崎秀 夫 (編) : 失語 - 失行 - 失認. 金原出版, 東京, 1982, pp. 59-68.

35）中村克樹：記憶とオシュレーション. 実験医学 12 ： 2540-2545， 1994.

36）小野武年，西条寿夫，上野照子：記憶における海馬体 の役割. 甘利俊一, 酒田英夫 (編) : 脳とニューラルネッ 卜. 朝倉書店, 東京, 1994, pp. 143-159.

37) Pons TP, Garraghty PE, Ommaya AK, Kaas JH, et al : Massive cortical reorganization after sensory deafferentation in adult Macaques. Science 252 : 1857-1860, 1991.

38) Yang TT, Gallen C, Schwartz B, Bloon FE: Sensory maps in the human brain. Nature 368:592 $-593,1994$.

39) Jenkins WM, Merzenich MM : Reorganization of neocortical representations after brain injury; A neurophysiological model of the bases of recovery from stroke. Prog Brain Res 71:249-266, 1987.

40) Jenkins WM, Merzenich MM, Ochs MT, Allard T, et al : Functional reorganization of primary somatosensory cortex in adult owl monkeys after behaviorally controlled tactile stimulation. J Neurophysiol 63:82-104, 1990.

41) Flor H, Elbert $T$, Knecht $S$, et al : Phantom-limb pain as a perceptual correlate of cortical reorgnization following arm amputation. Nature $375: 482$ $-484,1995$.

42) Kartje-Tillotson G, Neafsey EG, Castro AJ : Electrophysiological analysis of motor cortical plasticity after cortical lesions in newborn rats. Brain Res 332:103-111, 1985.

43) Donoghue JP, Suner S, Sanes JN : Dynamic organization of motor cortex output to target muscles in adult rats; II. Rapid reorganization following motor nerve lesions. Exp Brain Res 79 : 492-503, 1990.

44) Alvaro PL, Leonardo GC, Mark H : Cortical map 
plasiticity in humans. TINS $15: 13-14,1992$.

45）津本忠治：学習と記憶のシナップス過程. 甘利俊一, 酒田英夫 (編) : 脳とニューラルネット. 朝倉書店, 東 京, 1994, pp. 143-159.

46）塚田 稔：可塑性神経回路とそのモデル。 甘利俊一, 酒田英夫 (編) : 脳とニューラルネット。朝倉書店, 東 京, 1994, pp. 268-292.

47) Toyama K, Komatsu Y, Yamamoto N, Hirokohji $\mathrm{K}$ : In vitro studies of visual cortical development and plasticity. Prog Neurobiol $41:$ 543-563, 1993.

48) Garraghty PE, LaChica EA, Kaas JH : Injury-induced reorganization of somatosensory cortex is accompanied by reduction in GABA staining. Somatosens Mot Res 8:355-376, 1991.

49) Ades H, Raab DH : Recovery of motor function after two-stage extirpation of area 4 in monkeys. $\mathrm{J}$ Neurophysiol 9:55-60, 1946.

50) Irle $\mathrm{E}:$ An analysis of the correlation of lesion size, localization and behavioral effects in 283 published studies of cortical and subcortical lesions in old -world monkeys. Brain Res Rev 15:181-213, 1990.

51) White $\mathrm{HH}$ : Cerebral hemispherectomy in the treatment of infantile hemiplegia. Confin Neurol $21: 1$ $-50,1961$.

52) Travis AM, Woolsey CN : Motor performance of monkeys after bilateral partial and total cerebral decortications. Am J Phys Med 35 : 273-310, 1956.

53) Heinze HJ, Mangun GR, Burchert W, et al : Combined spatial and temporal imaging of brain activity during visual selective attention in humans. Nature 372:543-546, 1994.

54) Drevets WC, Burton H, Videen TO : Blood flow changes in human somatosensory cortex during anticipated stimulation. Nature $373: 249-252$, 1995.

\section{〉次号予告 \\ VOL. 32 NO. 11 \\ Editorial \\ 日本医大第二病院りハセンター 竹 内 孝 仁 \\ 第 32 回 日本リハビリテーション医学会学術集会 一般演題抄録（その 1 )}

編集の都合上内容が若干異なる場合がありますのでご了承下さい.

\section{ت囷肉}

\section{第 18 回 総合リハビリテーション研究大会}

日 時：1995 年 11 月 23 日（木), 24 日（金）

会 場：中央福祉学院（ロフォス湘南）

主 催：財団法人日本障害者リハビリテーション協会

テーマ:リハビリテーションの新たなる展開

一障害者施策の転換期にあたって一
問合せ先：

第 18 回総合リハビリテーション研究大会事務局 于 162 東京都新宿区戸山 1-22-1

（財）日本障害者リハビリテーション協会

๘203-5273-0601 Fax 03-5273-1523

\section{第 8 回 臨床神経生理学東京談話会}

\footnotetext{
日 時：1995 年 12 月 2 日（土） $14: 00 \sim 17 ： 30$

会 場：エーザイ株式会社・本館 5 階ホール

(文京区小石川 4-6-10 80 03-3817-5185)

会 費：1,000 円（会場整理費 - 通信連絡費）
}

\section{テーマ：眼球運動の神経機構}

連絡先: 東京都精神医学総合研究所 - 精神生理 臨床神経生理学東京談話会事務局（橋本勲）

\& 03-3304-5701 Fax 03-3329-8035 